\title{
ECHOES FROM THE PAST
}

\author{
SIR JAMES McGRIGOR BART, K.C.B., M.D., F.R.C.S., \\ COLONEL A. G. D. WHYTE, C.B.E., F.R.C.S., late R.A.M.C. \\ (continued from Volume 117, No. 4, 1971)
}

THE Journals presented by McGrigor to the Aberdeen Medico-Chirurgical Society in 1847 were they but notes and an aide memoire from which he prepared other official reports? It is remarked that in them he frequently omits figures of distances, numbers of admissions, discharges and remaining in hospital and so forth. Yet, such omissions would appear to be of essentials to an aide memoire. Are such statistics recorded elsewhere? They may be discovered in documents other than the Journal yet to be studied. Nor is the handwriting of Sir James of a high order. The copper-plate writing of the amanuensis, who wrote the letter to the Society in 1847 is in contrast to the difficult and sometimes quite undecipherable handwriting of McGrigor himself. So often and disappointingly it is a key word that remains so far un-revealed by effort and time. Nevertheless most of the principles of the medical care of armies in the field that he established and announced are quite clear and this is good.

In the Western Desert of the 1939.1945 War evacuation was over long distances, and the value of staging points on the way, where casualties could be checked and their creature comforts considered, was soon realised. This was appreciated by McGrigor soon after he arrived in Portugal and yet another principle of medical care in the field was established by him. He speaks as follows.

"I have said that the mortality at Coimbra had been very high and I saw that there was much severe and untreatable disease there. Many of the cases arrived in the last stages of fever or dysentery and many of the wounds were in a gangrenous state. To remedy this I established two intermediate or as they were called relay stations between Celerico andCoimbra. I placed there some medical officers with mattresses, bedding . . . . medical comforts. Notice being sent to these medical officers whenever sick were sent off from Celerico to have beds, warm . . . . and comforts in readiness for them by the time of their arrival."

The Journal is not without evidence of grim humour of which the following is an example. On his way to report to Wellington, one night he put up at a monastery near which a battle had recently taken place. While a meal was being prepared he was taken on a tour of the battle field by the Friar, who "pointed out the principal spots." McGrigor remarks "There was everywhere sufficient marks of remains of . . . French and English. The pious monk pulling me by the sleeve to one spot said this was a place where he found a wounded Frenchman whom he put out of pain by knocking his brain out with a stone." Surely Chaucer himself could not have conjured up a better word picture of one facet of human nature. This battle field was Bussaco anent which McGrigor makes the interesting observation about our oldest allies, the Portuguese.

"It was here that the Portuguese troops first fought in the ranks with the British and with them made a successful stand against the French to be seen the situation in which our army was most formidable, the ascent by which the French advanced bold and steep in the extreme." 


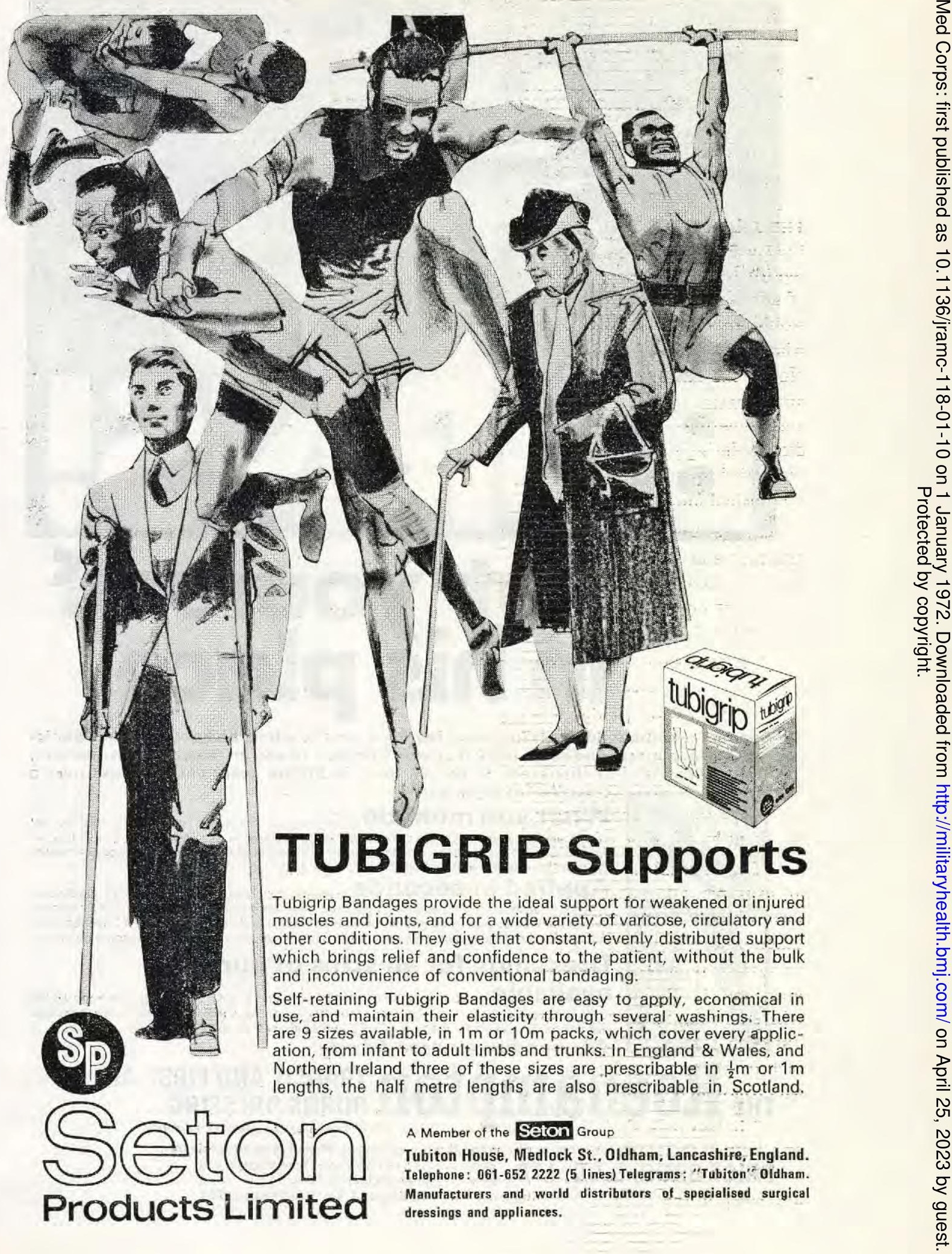



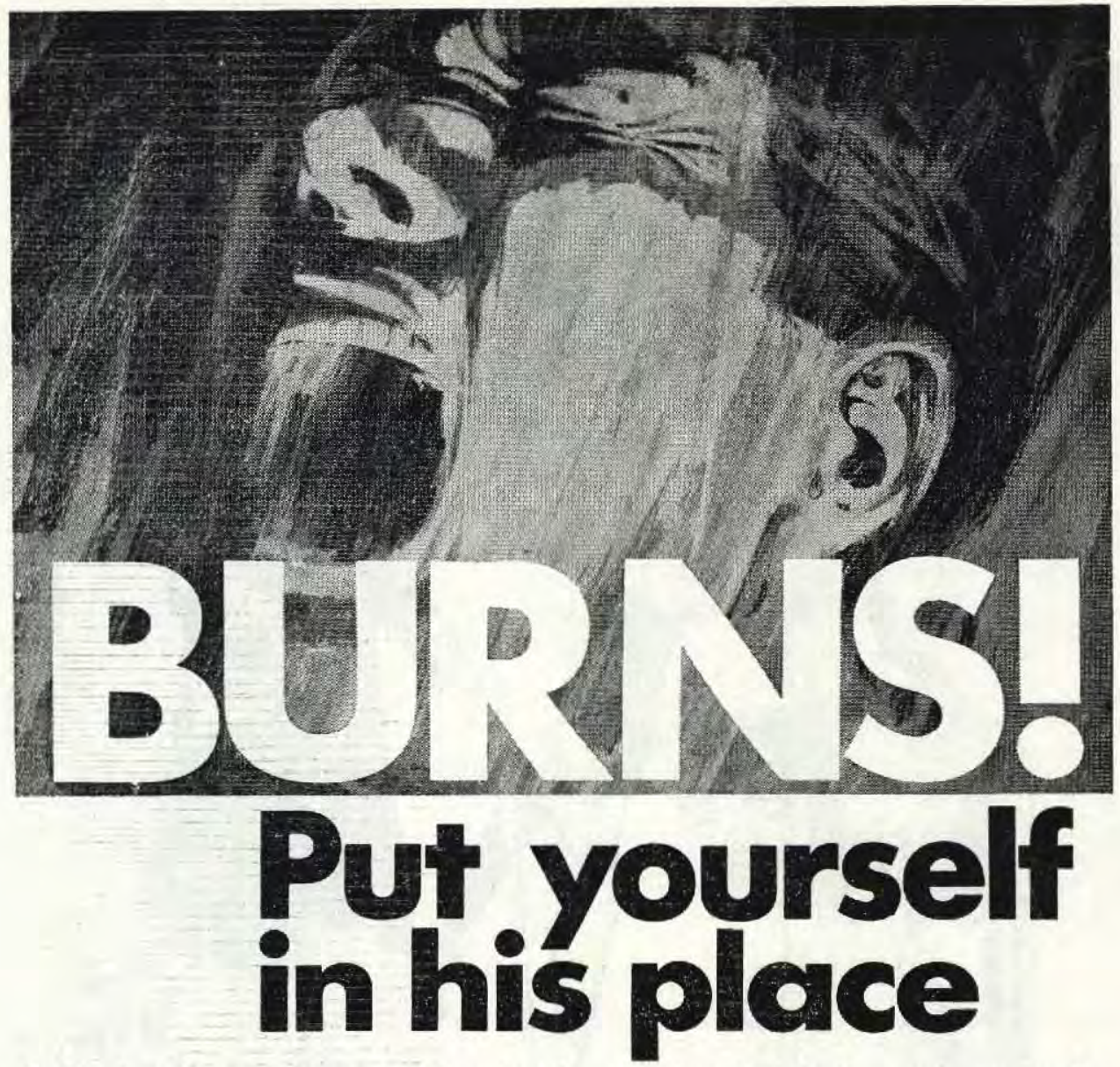

Sudde.Ily, without any warning, face, hands-even the whole body-can be an agonising, burning mass. And don't think it couldn't happen to you or the people around you. That's what tens of thousands of people think in Britain every year .... and over a

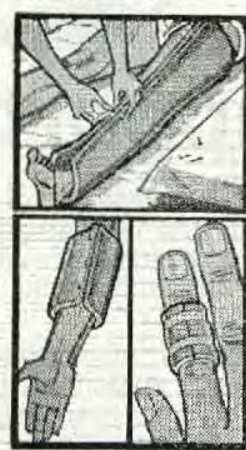
thousand of them die!

What you must do when serious burns do happen, it's vital to get skilled medical attention for the patient as quickly as possible. But before that, you must give first aid yourself ... dress the wound correctly with sterilised dressings that can be removed at the hospital-quickly and without causing extra pain.

Applied in seconds Roehampton Burns Dressings can be applied in seconds straight from the pack on to the burn-and removed just as quickly. They cause no unnecessary pain, give good protection against trauma and reduce the risk of infection. And you can be sure you're giving the patient the right, medically approved pre-hospital treatment.

\section{Dressings for all sizes of burn}

available New $^{\prime \prime \prime} \times 1 \frac{1}{\prime \prime}, 3^{\prime \prime} \times 3^{\prime \prime}, 12^{\prime \prime} \times 6^{\prime \prime}$ and $12^{\prime \prime} \times 12^{\prime \prime}$ dressings have been added to the larger dressings for arms, legs and whole body. So now with Roehampton Burns Dressings you can treat small, minor burns as quickly and easily as cuts and bruises.

\section{Always have some handy}

\section{Roehampton TRANSIT AND FIRST-AID THE Roehampton BURNS DRESSING}

Please write or phone for illustrated leaflet. Manufactured solely by

PRICE BROS. \& CO. LTD. Makers of the RELYON Triple Foan

Wellington, Somerset, England. Tel : Wellington 2216 
Sir James found many of the regiments in a very poor state of health, but one remark in this respect must gladden the heart of the Northern Scot. " At Vizeu I found another sickly regiment that was in Walcheren, though less sickly than the 26th, I mean the 75th or Cameron Highlanders. The stamina of those men was better than the 26th and they recovered and shortly became very effective with the army. The 26 th never rallied and it was found advisable to send them to Gibraltar."

Apart from disease and wounds there were other problems that do not change much with time regarding armies in the field. Sir James reports in his Journal of February 1812 as follows. "All adjoining villages about Celerico, were employed for accommodation of the sick .... there was wine in them all and the inhabitants lived by selling it to the soldiers." The morale of the Army must have suffered by the reputation of the medical services and hospitals to the extent that the Commander-in-Chief himself took heed and visited the hospital area before McGrigor's arrival. In the Journal we find it recorded "So unfavourable were reports in the Army regarding Celerico that Lord Wellington himself visited it in December 1811 and ordered 380 from it to Coimbra." Regretfully there have been similar occurrences since, such as in the earlier Mesopotamian campaign of the Kaiser's War. That there were no such disasters in the last great war speaks for itself as regards medical services and the pioneering work of Sir James McGrigor.

Wellington was obviously and painfully aware of the short comings of his medical services and he kept urging by letter that McGrigor should visit him at his Headquarters with the utmost speed. It seems to be without any shadow of doubt that McGrigor was hand-picked to clear up the mess, which he did. This has been so since, and it may be within recent memory that a Director-General at home, sending a new D.M.S. to a centre of operations abroad, simply stated to the Commander "I send you my very best medical officer." If ever anyone, that great Aberdonian Sir James McGrigor was the very best available, and he proved himself to be so. He must have met with much opposition in his task, but there is little if any evidence of this in the documents he left behind. He did not complain, he got on with the job in hand and it may be that he was quite ruthless in it. It is certain that he had the complete trust and support of Wellington, who obviously recognised that he had the man for the job and an invaluable asset to his campaign. " On my first interview with Lord Wellington I explained fully my views to his Lordship of the medical department and had the satisfaction to find a coincidence." Wellington may well have said what Montgomery wrote about the medical services in the 1939/1945 War on the signed copy of his photograph, which hangs in the Headquarters Mess of the Royal Army Medical Corps, " Presented to the Royal Army Medical Corps with admiration and high regard, and with gratitude to a Corps whose contribution to victory has been beyond all calculation."

McGrigor in due course, having put himself in the picture by close inspection of medical installations on the way " proceeded to Headquarters at Freynada to wait upon Viscount Wellington, Commander of the Forces."

As a result of his inspection Sir James had done a good deal of thinking on this journey. "Immediately on my joining Headquarters a number of things crossed my mind which I thought would be improvements in the Medical Department of the Army. I saw much of what appeared exceptionable to me. Nothing seemed worse than the mode of transporting the sick. This was oftenest done on the backs of mules or in the 
carts of the country. Another great evil always complained of was the difficulty of transporting stores to the hospital stations and to the Army. For transport of all kinds we are at all times dependent on the Commissariat." The efforts made by McGrigor on the problem of transport, though they at times brought rebuke from the Commanderin-Chief, surely led to the gradual but relentless improvement in this respect and to the present high standard of medical transport now enjoyed by land, sea and air. Like all good administrators McGrigor was a constructive critic. He was no "note-booker", the type who takes copious notes at inspections with little or no follow-up and action. He speaks thüs. " At each of the hospital stations which I visited on my way to the army, after inspections I wrote the remarks which inspection excited and left orders for the station." Such orders would be on the spot advice, mostly always acceptable and appreciated by willing subordinates.

Ever since, as it was in McGrigor's time, postings present problems. It is not uncommon for less enlightened regimental commanders, wishing not un-naturally to retain known and trusted medical officers, to resist postings, which are made for the benefit of the service as a whole. No one is indispensable, a humbling truth. In a service where casualties of all kinds can occur, each should be capable of undertaking the duty of the other. McGrigor met and solved this problem and he may be quoted as he makes a pronouncement to stand for all time. "I early determined that there should be no permanent or fixed situation but that my medical officers of whatever rank in the Army should be moveable and hold himself in readiness for all duties." This is surely a worthwhile principle, applicable even in this day of specialisation. Economy of medical resources requires that each be employed in his capacity to the best advantage of all. Verily James McGrigor founded more firmly than he knew and time has only served to confirm his judgements.

There is no special guardian angel fluttering over medical personnel to protect them, and they suffered no less than the fighting man from the prevalent diseases of the campaign. The Journal records thus in February 1812.

"In my letter to the Board from Celerico dated 16th, I informed them that the prevailing fever.which was contagious had attacked Dr. McAffan the P.M.O. The deaths here were more considerable than at Coimbra: From 25th October to 24th January the deaths were 618 , the general number in hospital being .... and in this period 15 medical officers were attacked with fever and a very great proportion of hospital servants."

"I find by a statement of Mr. McLean the P.M.O. at Celerico that from the 25th October 1811 to 24th January 1812, the total number of deaths had been 618 their diseases having been Fever and intermittents originally but terminating in Dropsy or Dysentery. In the same period there died 11 hospital mates! - every one of them of simple continued fever: Mr. McLean further states that $\frac{3}{4}$ of the wardmasters, orderlies, and nurses were . . . . with fever in a very few days after their admission as hospital servants."

Another hospital area calls for this observation "Much fever had prevailed at Castaniera, which proved fatal to several officers of the hospital department." Moreover disease is no respecter of persons or rank as the following entry shows. "Dr. Snow physician and Staff Surgeon Price were detached with the expedition under General Ross to Carthagena, where the General and Dr. Snow were carried off by the prevailing 
fever." This apparently laconic statement tells a sorry tale of the dangers of campaigning in days not too long gone by.

Yet all stations in the Peninsula were not unhealthy, all the time anyhow, and this note occurs in the Journal. "By a communication from Sir James Fellowes on the 28th (February 1812) I learned that Cadiz continued so very healthy that he had broke up the general hospital there."

Every now and then McGrigor gives statistics of hospital admissions and deaths, breaking them down into diseases. It is noteworthy that as many were admitted with what he calls Continued Fever and Intermittent as with wounds. Deaths from fevers and dysentery far outnumbered those from wounds during the campaign except during the set pieces. During periods of increased activity, for example the siege of Badajoz, the number of admissions for wounds increased very considerably and approached the combined admissions for Continued and Intermittent Fever. During this stage the general hospitals admissions, and this does not include admissions to the so-called regimental hospitals, between 21st March and 20th April were some 9000, with 1800 cases of Continued Fever, 220 Intermittent and 4500 wounded.

He recognised the importance of acclimatisation of personnel preceeding overseas. This looms large these days of rapid transport, as if it were something new, but McGrigor was aware of it at the beginning of last century. Healthy recruitment he emphasised and we would agree even at the present time with his finding that the agricultural worker was a better physical specimen for overseas services taken by and large than the town dweller. Medical examination and selection of men proceeding overseas, a period at the base abroad before joining front line troops were matters of insistence with him. We would like to think of our Field Dressing Stations so useful and successful in the last was as being a modern concept but it was James McGrigor who first made them. $\mathrm{He}$ established the value of forward treatment and of evacuation to base hospital of certain cases only. He first saw and carried out the segregation of patients with separate accommodation for surgical, medical, infectious and other conditions. He instituted medical administration instructions, circulated to all medical officers, standardisation of procedures techniques and therapies, so essential in dealing with conditions in the field. Accommodation, provisions, clothing, water supplies, transport, recreation all that we know today swam into his ken.

McGrigor was no mean psychiatrist and he knew the value of high morale. $\mathrm{He}$ persuaded the Duke of Wellington, and I quote " to cherish the exertions of medical personnel and above all to gratify them by that public notice which heretofore had been confined to the military department of the army; a notice and applause which brings them on the future pages of the history of their country."

At the close of the brilliant Peninsula campaign with the all too apparent success of the medical services, McGrigor insists on the value of the services of his medical colleagues of whom he was privileged to be the chief I quote:

"The services of medical officers may be of a less brilliant nature than those of the military: but in points of utility, talent and zeal, $I$ believe it was acknowledged that the medical officer was not inferior to any department in the Army under the Duke of Wellington, contributing most largely to a successful issue of the contest in which we were engaged." 
Further comment on the McGrigor papers may be made from time to time, but the thoughts here recorded may renew interest in and appreciation of the life and work of this remarkable man in this bi-centenary of his death.

(Concluded)

\section{Appointments to the Queen}

Brigadier T. H. P. McKelvey, M.A., M.B., B.Chir., F.R.C.P., has been appointed Honorary Physician to The Queen, in succession to Brigadier A. F. H. Keatinge.

Brigadier S. H. Janikoun, O.B.E., F.R.C.S., L.R.C.P., has been appointed Honorary Surgeon to The Queen, with effect from 1 October 1971, in succession to Major-General J. M. Matheson, who has retired.

\section{ACADEMIC ACHIEVEMENTS}

F.F.R.

Diploma of Dermatology

D.C.H.
MAjor B. J. LOVEDAY, M.B., B.S., D.M.R.D., R.A.M.C.

Lieutenant-Colonel. D. Sim-Dayis, M.R.C.S., L.R.C.P., D.T.M. \& H., R.A.M.C. (Jointly awarded the Chesterfield Medal in Dermatology).

CAPTAIN D. K. GRIEVE, M.R.C.S., L.R.C.P., R.A.M.C.

CAPTAIN P. J. HoYTE, M.R.C.S., L.R.C.P., R.A.M.C.

Captain A. J. Williams, M.B., ch.B., R.A.M.c. 